\title{
Reduced Activation of the Synaptic-Type GABA Receptor Following Prolonged Exposure to Low Concentrations of Agonists: Relationship between Tonic Activity and Desensitization
}

\author{
Spencer R. Pierce, Allison L. Germann, Alex S. Evers, Joe Henry Steinbach, \\ and Gustav Akk \\ Department of Anesthesiology (S.R.P., A.L.G., A.S.E., J.H.S., G.A.) and the Taylor Family Institute for Innovative Psychiatric \\ Research (A.S.E., J.H.S., G.A.), Washington University School of Medicine, St. Louis, Missouri
}

Received June 11, 2020; accepted September 9, 2020

\section{ABSTRACT}

Synaptic $\mathrm{GABA}_{\mathrm{A}}$ receptors are alternately exposed to short pulses of a high, millimolar concentration of GABA and prolonged periods of low, micromolar concentration of the transmitter. Prior work has indicated that exposure to micromolar concentrations of GABA can both activate the postsynaptic receptors generating sustained low-amplitude current and desensitize the receptors, thereby reducing the peak amplitude of subsequent synaptic response. However, the precise relationship between tonic activation and reduction of peak response is not known. Here, we have measured the effect of prolonged exposure to GABA or the combination of GABA and the neurosteroid allopregnanolone, which was intended to desensitize a fraction of receptors, on a subsequent response to a high concentration of agonist in human $\alpha 1 \beta 3 \gamma 2 \mathrm{~L}$ receptors expressed in Xenopus oocytes. We show that the reduction in the peak amplitude of the post-exposure test response correlates with the open probability of the preceding desensitizing response. Curve fitting of the inhibitory relationship yielded an $\mathrm{IC}_{50}$ of $12.5 \mu \mathrm{M}$ and a Hill coefficient of -1.61 . The activation and desensitization data were mechanistically analyzed in the framework of a three-state Resting-Active-Desensitized model. Using the estimated affinity, efficacy, and desensitization parameters, we calculated the amount of desensitization that would accumulate during a long (2-minute) application of GABA or GABA plus allopregnanolone. The results indicate that accumulation of desensitization depends on the level of activity rather than agonist or potentiator concentration per se. We estimate that in the presence of $1 \mu \mathrm{M}$ GABA, approximately $5 \%$ of $\alpha 1 \beta 3 \gamma 2 \mathrm{~L}$ receptors are functionally eliminated because of desensitization.

\section{SIGNIFICANCE STATEMENT}

We present an analytical approach to quantify and predict the loss of activatable GABA receptors due to desensitization in the presence of transmitter and the steroid allopregnanolone. The findings indicate that the peak amplitude of the synaptic response is influenced by ambient GABA and that changes in ambient concentrations of the transmitter and other GABAergic agents can modify tonically and phasically activated synaptic receptors in opposite directions.

\footnotetext{
Primary laboratory of origin: Washington University School of Medicine, St. Louis, MO (G.A.)

This work was supported by National Institutes of Health National Institute of General Medical Sciences [Grants R01-GM108580 and R01-GM108799] and funds from the Taylor Family Institute for Innovative Psychiatric Research. https://doi.org/10.1124/molpharm.120.000088.
}

\section{Introduction}

The neurotransmitter receptors in the brain are exposed to two regimes of extracellular transmitter concentration: Throughout the brain an ambient, tonic concentration is present (although not necessarily constant or uniform), whereas near the synapse the phasic release of transmitter can result in concentrations as high as millimolar in the synaptic cleft. Extrasynaptic receptors close to the synapse

ABBREVIATIONS: ACh, acetylcholine; IPSC, inhibitory postsynaptic current; L, ratio of resting to active receptors; $3 \alpha 5 \alpha \mathrm{P}, 1$-[(3R,5S,8R,9S,10S,13S,14S,17S)3-hydroxy-10,13-dimethyl-2,3,4,5,6,7,8,9,11,12,14,15,16,17-tetradecahydro-1H-cyclopenta[a]phenanthren-17-yl]ethanone (allopregnanolone); $\mathrm{P}_{\mathrm{A}}$, probability of being in the active state; $\mathrm{P}_{\mathrm{A} \text {,peak }}$, peak $\mathrm{P}_{\mathrm{A}} ; \mathrm{P}_{\mathrm{A}}$, steady-state $\mathrm{P}_{\mathrm{A}} ; \mathrm{P}_{\mathrm{D}}$, probability of being in the desensitized state; $\mathrm{P}_{\mathrm{D} \text {,s.s. }}$, steady-state $P_{D} ; P_{R, s . s .}$, steady-state probability of being in the resting state; $Q$, ratio of active to desensitized receptors; RAD, RestingActive-Desensitized. 
experience reduced and slower transients, whereas receptors far from the synapse likely experience even slower and less extreme variations.

$\mathrm{GABA}_{\mathrm{A}}$ receptors in the postsynaptic membrane are activated by presynaptically released GABA, whose concentration in the synaptic cleft reaches $1-5 \mathrm{mM}$ at its peak (Clements, 1996; Mozrzymas et al., 1999; Overstreet et al., 2002). The synaptic response, reflecting activated receptors with open channels, decays with a decay time constant on the timescale of tens of milliseconds as channels close and transmitter dissociates from the receptor. The concentration transient itself is more rapid and is terminated in part by binding to the receptor and eventually by removal by membrane transporters and diffusion (Edwards et al., 1990; Jones and Westbrook, 1995; Draguhn and Heinemann, 1996; Mozrzymas et al., 1999). Between synaptic events, the activity due to exposure to ambient GABA is low, although the integrated charge transfer during exposure to ambient GABA may actually exceed that during a short-lasting synaptic event within the same time period (Germann et al., 2019b).

Prolonged exposure to low concentrations of GABA can also desensitize the $\mathrm{GABA}_{\mathrm{A}}$ receptor (Orser et al., 1994; Overstreet et al., 2000) even when the amplitude of the response is small. This manifests as reduction in the peak amplitude of inhibitory postsynaptic currents (IPSCs) or a decrease in the peak response to subsequent test application of agonist. The effect is observed at concentrations of GABA that are close to the estimated ambient tonic level. However, there is no clear theoretical framework for understanding the relationship between tonic levels of activity and phasic responses. This relationship is particularly interesting in the case of $\mathrm{GABA}_{\mathrm{A}}$ receptors because their activity is known to be modulated by both endogenous and exogenous chemicals that could affect one or both of the tonic and phasic responses.

Here, we have measured receptor desensitization by exposing cells expressing the human $\alpha 1 \beta 3 \gamma 2 \mathrm{~L}$ receptor to GABA or the combination of GABA and the neurosteroid allopregnanolone $(3 \alpha 5 \alpha \mathrm{P})$ and then comparing pre-exposure and postexposure responses to a high concentration of agonist to characterize the phasic response. We were motivated to understand how increases in ambient concentrations of endogenous GABAergic agents increase tonic activity but may somewhat counterintuitively reduce the amplitude of the phasic response. Employing a three-state cyclic RestingActive-Desensitized model, we show that the loss of activatable receptors can be satisfactorily predicted using the activation and desensitization parameters of the receptor estimated in separate experiments. The data indicate that the reduction in available activatable receptors correlates with the open probability of the preceding desensitizing response.

\section{Methods}

The human $\alpha 1 \beta 3 \gamma 2 \mathrm{~L}$ GABA $_{\mathrm{A}}$ receptors were expressed in Xenopus laevis oocytes purchased from Xenoocyte (Dexter, MI) as quarter ovaries. Ovaries were digested in $2 \% \mathrm{w} / \mathrm{v}$ (milligrams per milliliter) collagenase A solubilized in ND96 (96 mM NaCl, $2 \mathrm{mM} \mathrm{KCl,} 1.8 \mathrm{mM} \mathrm{CaCl}, 1 \mathrm{mM} \mathrm{MgCl}_{2}$, $5 \mathrm{mM}$ HEPES; pH 7.4) plus $100 \mathrm{U} / \mathrm{ml}$ penicillin and $100 \mu \mathrm{g} / \mathrm{ml}$ streptomycin at $37^{\circ} \mathrm{C}$ with shaking at $250 \mathrm{rpm}$ for $30-40$ minutes. After digestion, the oocytes were rinsed clean of collagenase A in ND96 and stored in ND96 with supplements (2.5 mM Na pyruvate, $100 \mathrm{U} / \mathrm{ml}$ penicillin, $100 \mu \mathrm{g} / \mathrm{ml}$ streptomycin, $50 \mu \mathrm{g} / \mathrm{ml}$ gentamycin) at $15^{\circ} \mathrm{C}$ for at least 4 hours before injection.

The cDNAs for human $\alpha 1$ (GenBank accession NM_000806), $\beta 3$ (NM_000814), and $\gamma 2 \mathrm{~L}$ (NM_198904) subunits in the pcDNA3 vector were linearized with XbaI (NEB Laboratories, Ipswich, MA), and the complementary RNAs were generated using mMessage mMachine (Ambion, Austin, TX). The oocytes were injected with a total of $3.5 \mathrm{ng}$ of complementary RNA in the ratio of $1: 1: 5(\alpha: \beta: \gamma)$ per oocyte and incubated in ND96 (96 mM NaCl, $2 \mathrm{mM} \mathrm{KCl,} 1.8 \mathrm{mM} \mathrm{CaCl}_{2}, 1 \mathrm{mM} \mathrm{MgCl}_{2}, 5 \mathrm{mM}$ HEPES; $\mathrm{pH} 7.4$ ) with supplements at $15^{\circ} \mathrm{C}$ for 1 to 2 days prior to conducting electrophysiological recordings.

The electrophysiological recordings were conducted at room temperature using standard two-electrode voltage clamp. The oocytes were clamped at $-60 \mathrm{mV}$. Bath and drug solutions were gravity-applied from glass syringes equipped with glass luer slips via Teflon tubing to the recording chamber (RC-1Z; Warner Instruments, Hamden, CT) at the rate of $6-8 \mathrm{ml} / \mathrm{min}$.

The current responses were amplified with an OC-725C amplifier (Warner Instruments), filtered at $30 \mathrm{~Hz}$ with a lowpass Bessel filter (Model 900; Frequency Devices, Ottawa, IL), digitized at $100 \mathrm{~Hz}$ with a Digidata 1200 series digitizer (Molecular Devices, San Jose, CA), and stored using pClamp (Molecular Devices). Analysis of the current traces with respect to peak and steady-state amplitudes was done with Clampfit (Molecular Devices).

The effect of exposure to a desensitizing agonist was determined as follows. First, the cells were repeatedly activated by brief (10-15-second) applications of a test agonist (1 mM GABA in experiments employing GABA as the desensitizing agonist and $1 \mathrm{mM} \mathrm{GABA}+1 \mu \mathrm{M} 3 \alpha 5 \alpha \mathrm{P}$ in experiments involving the combination of $\mathrm{GABA}+3 \alpha 5 \alpha \mathrm{P}$ as the desensitizing agonist) until a stable peak response (less than $10 \%$ change between consecutive responses) was observed. The washout time between successive applications of the test agonist was 3 minutes. It took between three and eight applications to obtain a stable response. If a stable response to test agonist was not attained by the eighth application, the cell was discarded. Each cell was then exposed to a 1-minute wash in bath followed by a 2-minute desensitizing application of GABA or the combination of GABA $+3 \alpha 5 \alpha \mathrm{P}$. This was immediately followed by another application of the test agonist. The fraction of receptors desensitized during exposure to the desensitizing agonist was determined as 1 - the ratio between the peak amplitudes of postexposure and the last pre-exposure responses. Pilot experiments with varying exposure and washout times indicated that a 2-minute exposure to the desensitizing agonist was sufficient to reach steady state.

Receptor activation by GABA was recorded by exposing the cells to 1.5-5-minute applications of $0.3 \mu \mathrm{M}$ to $1 \mathrm{mM}$ GABA. To minimize measurement error associated with long-duration recordings, each cell was exposed to only one to two concentrations of GABA rather than to a full range of agonist concentrations. Each cell was also tested with $1 \mathrm{mM}$ GABA $+50 \mu \mathrm{M}$ propofol that was considered to activate all receptors (Shin et al., 2018). Peak and steady-state open probabilities $\left(\mathrm{P}_{\mathrm{A} \text {,peak }}\right.$ and $\mathrm{P}_{\mathrm{A}, \text { s.s. }}$, respectively) were estimated by normalizing peak and steady-state amplitudes in the presence of GABA to the peak response to GABA + propofol. The peak open 
probability and the ratio of steady-state to peak responses in the presence of saturating GABA are similar to those previously estimated in whole-cell and single-channel recordings from human embryonic kidney cells (Steinbach and Akk, 2001; Bianchi and Macdonald, 2002; Feng et al., 2004). The data from different cells were pooled and averaged for analysis. Curve fitting was done using Origin 2020 (OriginLab Corp., Northampton, MA). Parameters estimated by fitting models to the data are presented as best fitting value \pm estimated S.D. of the fit.

The findings are reported according to the guidelines detailed in Michel et al. (2020). The sample sizes ranged from five to seven cells for individual experiments. All data for each individual experiment were collected before conducting data analysis. All data are included in analysis and are presented as mean \pm S.D. The study is exploratory by nature.

\section{Results}

Prolonged Exposure to GABA Reduces the Number of Activatable Receptors: Description of the Phenomenon. Sample traces in Fig. 1 show the loss of activatable receptors due to desensitization. Peak responses to brief test applications of $1 \mathrm{mM}$ GABA were compared before and after a 2-minute desensitizing application of $1 \mu \mathrm{M}$ (Fig. 1A) or $300 \mu \mathrm{M}$ GABA (Fig. 1B). The response to the test application after exposure to $1 \mu \mathrm{M}$ GABA (test application \#2) was $0.94 \pm$ 0.04 (mean \pm S.D.; $n=6$ cells) of the test response before exposure to $1 \mu \mathrm{M}$ GABA (test application \#1). After exposure to $300 \mu \mathrm{M}$ GABA, the ratio of responses was $0.29 \pm 0.11(n=5$ cells).

The ratio of amplitudes of responses to the test application as a function of the concentration of GABA in the desensitizing application is shown in Fig. 1C. Fitting the Hill equation to the data yielded a maximal response of $0.94 \pm 0.02$ (best-fit parameter \pm S.D. of the fit), a minimal response of $0.30 \pm$ 0.02 , an $\mathrm{IC}_{50}$ of $12.5 \pm 1.4 \mu \mathrm{M}$, and an $n_{\mathrm{H}}$ of $-1.61 \pm 0.26$. The nonzero minimal response closely corresponds to the steady-state response to saturating GABA in the related $\alpha 1 \beta 2 \gamma 2 \mathrm{~L}$ receptor (Germann et al., 2019b).

The Resting-Active-Desensitized Model Predicts Accumulation of Receptors in the Desensitized State During Exposure to Agonist. We postulate that the decrease in the amplitude of the test response after prolonged exposure to GABA, as illustrated in Fig. 1, is due to accumulation of a fraction of receptors in the desensitized state. These receptors are neither active nor activatable after exposure to the desensitizing application of GABA and thus do not contribute to the second test response.

We explored desensitization in the framework of the threestate Resting-Active-Desensitized (RAD) model (Fig. 2). The model is based on the Monod-Wyman-Changeux two-state cyclic model originally used to describe enzyme function (Monod et al., 1965). In the RAD model, an additional inactive state is placed beyond the active state. This enables analysis of equilibrium activity from transmitter-gated channels that undergo transition to a nonconducting, high-affinity state upon prolonged exposure to agonist ("desensitization"). The critical aspects of the RAD model are: 1) a ligand can have different affinities to different states; 2) the individual sites for a ligand in a given state have identical binding properties; and 3 ) the receptor undergoes a concerted state transition in which
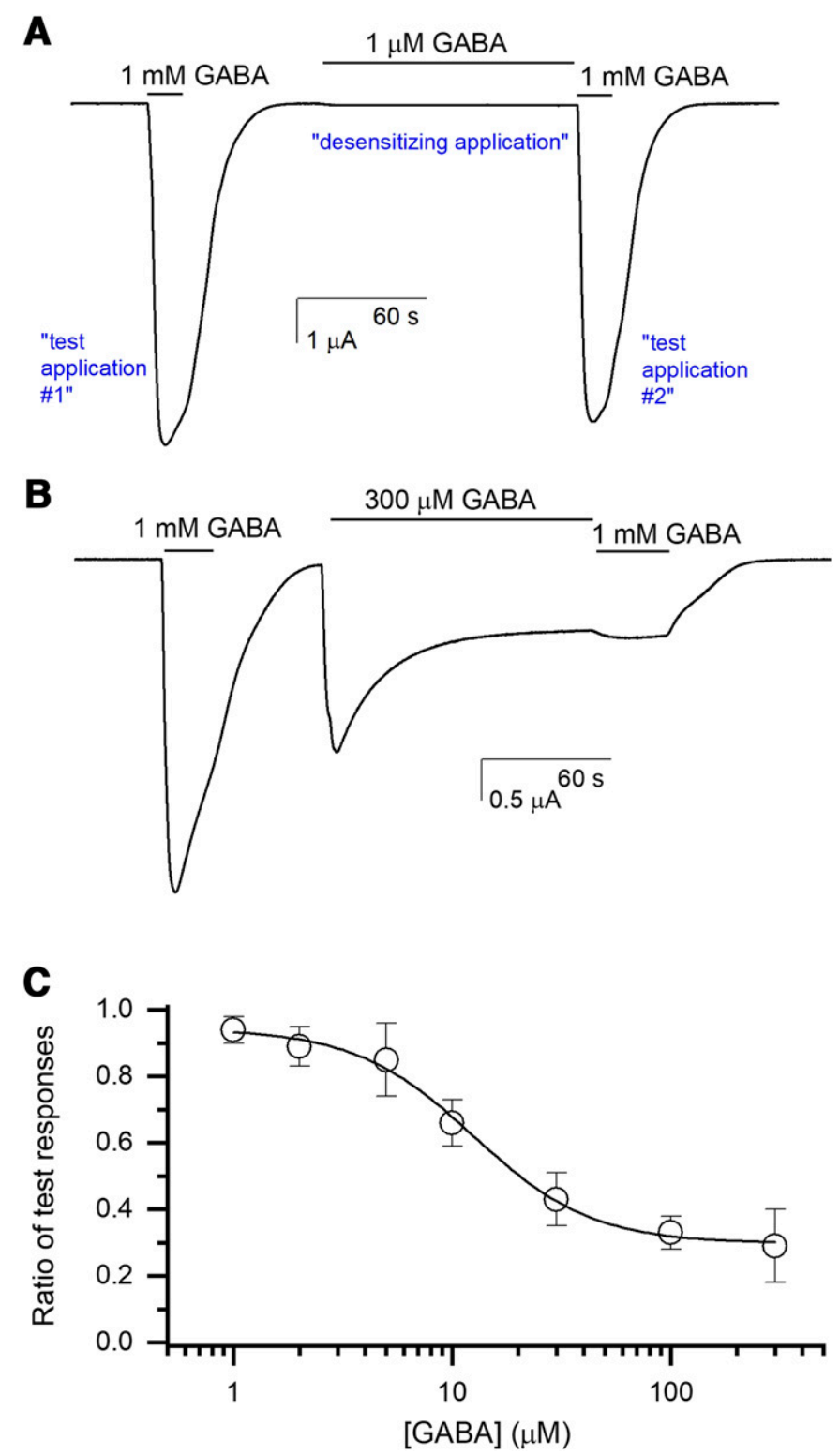

Fig. 1. Prolonged exposure to GABA reduces the number of activatable receptors. The current traces show responses to brief applications of $1 \mathrm{mM}$ GABA before ("test application \#1") and after ("test application \#2") a 2-minute desensitizing application of $1 \mu \mathrm{M}$ (A) or $300 \mu \mathrm{M}$ GABA (B). (C) shows the GABA concentration dependence of the ratio of amplitudes of test responses (test application \#2/test application \#1). The data show mean \pm S.D. from five to seven cells per concentration. Each cell was exposed to a single concentration of GABA. The curve was fitted with the Hill equation. The $\mathrm{IC}_{50}$ of the curve is $12.5 \mu \mathrm{M}$, the Hill coefficient is -1.61 , and the high concentration asymptote is 0.30 .

all sites change properties simultaneously. We have previously employed the RAD model to analyze steady-state activity in $\alpha 1 \beta 2 \gamma 2 \mathrm{~L}$ and $\alpha 4 \beta 2 \delta \mathrm{GABA}_{\mathrm{A}}$ receptors (Germann et al., 2019a,b; Pierce et al., 2019).

In the $\mathrm{RAD}$ model, the fraction of receptors in the $\mathrm{D}$-state at a given agonist concentration depends on the parameters $\mathrm{L}$ (the ratio of resting to active receptors; R/A in Fig. 2) and $\mathrm{Q}$ (the ratio of active to desensitized; A/D in Fig. 2). A lower value of $\mathrm{L}$ (more active vs. resting) and a lower value of $\mathrm{Q}$ (more desensitized vs. active) increase the fraction of receptors in the D-state. 


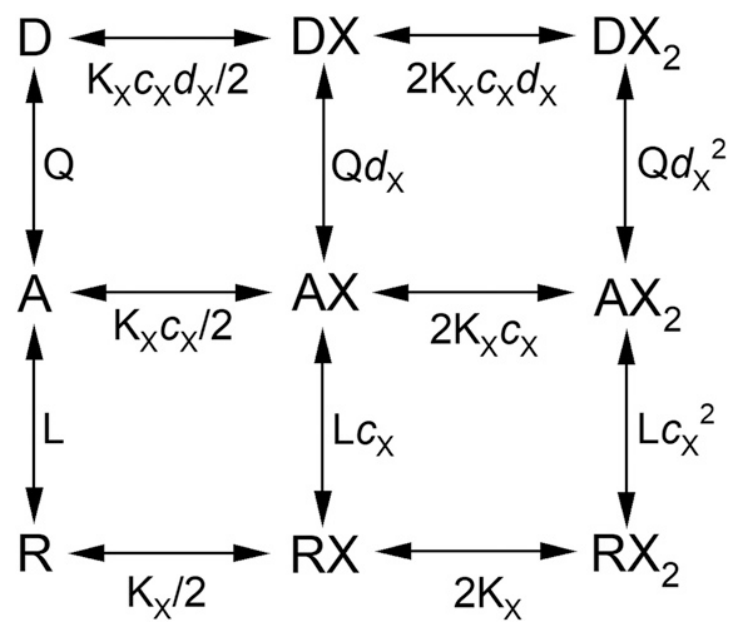

Fig. 2. A three-state Resting-Active-Desensitized model. The receptor can occupy a resting (R), active (A), or desensitized (D) state. The receptor has two binding sites for ligand X. The parameter $\mathrm{L}(=\mathrm{R} / \mathrm{A})$ describes the equilibrium between the resting and active states. The parameter $\mathrm{Q}(=\mathrm{A} /$ D) describes the equilibrium between the active and desensitized states. $\mathrm{K}_{\mathrm{X}}, \mathrm{K}_{\mathrm{X}} c_{\mathrm{X}}$, and $\mathrm{K}_{\mathrm{X}} c_{\mathrm{X}} d_{\mathrm{X}}$ are the equilibrium dissociation constants for $\mathrm{X}$ in the resting, active, and desensitized receptor, respectively.

Formally, the steady-state probability of being in the active state at a given concentration of agonist $\mathrm{X}$ is:

$$
\mathrm{P}_{\mathrm{A}, \text { s.s. },[\mathrm{X}]}=\frac{1}{1+\frac{1}{\mathrm{Q}}\left[\frac{1}{\left(\frac{\left.1+[\mathrm{X}] / \mathrm{K}_{\mathrm{X}} c_{\mathrm{X}}\right)}{1+[\mathrm{X}] /\left(\mathrm{K}_{\mathrm{X}} c_{\mathrm{X}} \mathrm{X}_{\mathrm{X}}\right)}\right)^{\mathrm{N}_{\mathrm{X}}}}\right]+\mathrm{L}\left[\frac{1+[\mathrm{X}] / \mathrm{K}_{\mathrm{X}}}{1+[\mathrm{X}] /\left(\mathrm{K}_{\mathrm{X}} c_{\mathrm{X}}\right)}\right]^{\mathrm{N}_{\mathrm{X}}}}=\frac{1}{1+\frac{1}{\mathrm{Q} \Delta_{\mathrm{X}}}+\mathrm{L} \Gamma_{\mathrm{X}}}
$$

in which $[\mathrm{X}]$ is the concentration of agonist $\mathrm{X}, \mathrm{K}_{\mathrm{X}}$ is the equilibrium dissociation constant for $\mathrm{X}$ in the resting state, $c_{\mathrm{X}}$ is the ratio of the equilibrium dissociation constants in the active and resting states, $d_{\mathrm{X}}$ is the ratio of the equilibrium dissociation constants in the desensitized and active states, and $N_{X}$ is the number of binding sites for $X$. The parameters $L$ and $\mathrm{Q}$ are as described earlier. $\Delta_{\mathrm{X}}$ and $\Gamma_{\mathrm{X}}$ are defined as:

$$
\Delta_{\mathrm{X}}=\left[\frac{1+[\mathrm{X}] /\left(\mathrm{K}_{\mathrm{X}} c_{\mathrm{X}}\right)}{1+[\mathrm{X}] /\left(\mathrm{K}_{\mathrm{X}} c_{\mathrm{X}} d_{\mathrm{X}}\right)}\right]^{\mathrm{N}_{\mathrm{X}}}
$$

and

$$
\Gamma_{\mathrm{X}}=\left[\frac{1+[\mathrm{X}] / \mathrm{K}_{\mathrm{X}}}{1+[\mathrm{X}] /\left(\mathrm{K}_{\mathrm{X}} c_{\mathrm{X}}\right)}\right]^{\mathrm{N}_{\mathrm{X}}}
$$

We have assumed that $d_{\mathrm{GABA}}=1$, so $\Delta_{\mathrm{GABA}}=1$.

The steady-state probability of being in the desensitized state is:

$$
\mathrm{P}_{\mathrm{D}, \mathrm{s} . \mathrm{s} .,[\mathrm{X}]}=\frac{1}{1+\mathrm{Q} \Delta_{\mathrm{X}}+\mathrm{Q} \Delta_{\mathrm{X}} \mathrm{L} \Gamma_{\mathrm{X}}}
$$

$\mathrm{P}_{\mathrm{R} \text {,s.s. }}$, the steady-state probability of being in the resting state, can be calculated as $1-\mathrm{P}_{\mathrm{A} \text {,s.s. }}-\mathrm{P}_{\mathrm{D} \text {,s.s. }}$.

Figure 3 illustrates simulated probability distributions in resting, active, and desensitized states at a range of concentrations of agonist $\mathrm{X}$. For the calculations, $\mathrm{K}_{\mathrm{X}}$ was held at $10 \mu \mathrm{M}, c_{\mathrm{X}}$ was $0.005, d_{\mathrm{X}}$ was 1 , and $\mathrm{N}_{\mathrm{X}}$ was 2 . In the absence of $\mathrm{X}$, the vast majority $(>99 \%)$ of receptors are in the resting state (i.e., $\mathrm{P}_{\mathrm{R} \text {,s.s. }}>0.99$ ). As the concentration of $\mathrm{X}$ is increased,
$\mathrm{P}_{\mathrm{R} \text {,s.s. }}$ decreases (Fig. 3A). This is accompanied by increases in the peak and steady-state probabilities of being active $\left(\mathrm{P}_{\mathrm{A} \text {,peak }}\right.$ and $\mathrm{P}_{\mathrm{A}, \text { s.s. }}$, respectively) as well as desensitized ( $\left.\mathrm{P}_{\mathrm{D} \text {,s.s. }}\right)$.

This study is focused on the fraction of receptors that is active or available for activation by agonist as a function of tonic activity. This relationship is shown in Fig. 3B for different values of $\mathrm{Q}$ reflecting the ratio of active to desensitized receptors. The calculations indicate that as $\mathrm{P}_{\mathrm{A} \text {,s.s. }}$. increases, the fraction of available receptors decreases steadily. In the absence of agonist, $\mathrm{P}_{\mathrm{A} \text {,s.s. }}=1 /(1+1 / \mathrm{Q}+\mathrm{L})$ and $\mathrm{P}_{\mathrm{D} \text {,s.s. }}=(1 / \mathrm{Q}) \times \mathrm{P}_{\mathrm{A} \text {,s.s. }}$, whereas in the presence of a saturating concentration, $\mathrm{P}_{\mathrm{A}, \mathrm{s.s} .}=1 /\left(1+1 /\left(\mathrm{Q} d^{\mathrm{N}}\right)+\mathrm{L} c^{\mathrm{N}}\right)$ and $\mathrm{P}_{\mathrm{D} \text {,s.s. }}=(1 /$ $\left.\left(\mathrm{Qd}^{\mathrm{N}}\right)\right) \times \mathrm{P}_{\mathrm{A}}$.
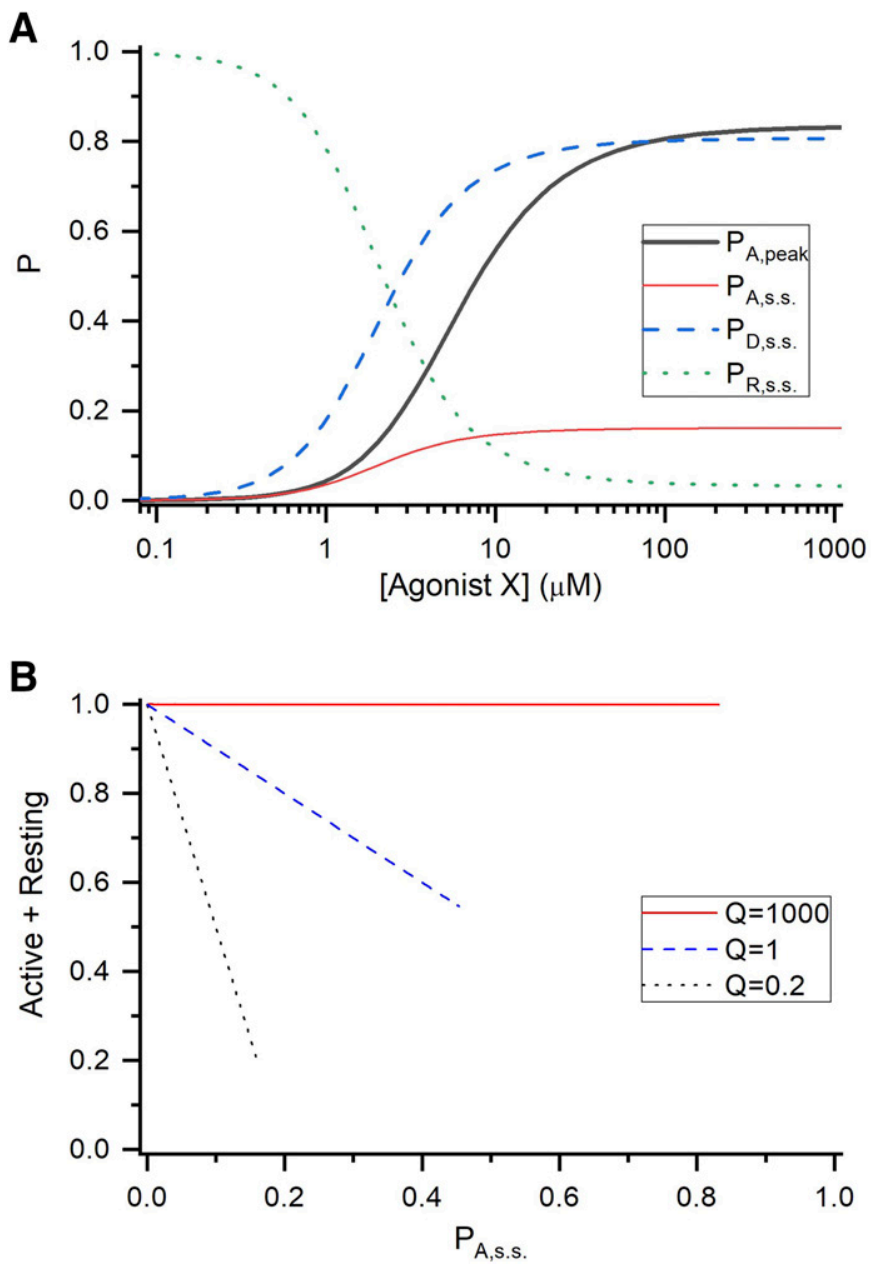

Fig. 3. Calculated probability distributions. (A) shows the probabilities of being in the resting $\left(\mathrm{P}_{\mathrm{R}, \mathrm{s.s} .}\right)$, active $\left(\mathrm{P}_{\mathrm{A} \text {,peak }}\right.$ and $\left.\mathrm{P}_{\mathrm{A} \text {,s.s. }}\right)$, or desensitized states $\left(\mathrm{P}_{\mathrm{D}, \mathrm{s.s}}\right)$ at various concentrations of agonist $\mathrm{X}$. The modeling was done using the values of $\mathrm{L}$ of 8000 and $\mathrm{Q}$ of 0.2 . The equilibrium dissociation constant of $\mathrm{X}$ in the resting state $\left(\mathrm{K}_{\mathrm{X}}\right)$ was assigned a value of $10 \mu \mathrm{M}, c_{\mathrm{X}}$ was 0.005 , and $d_{\mathrm{X}}$ was $1 . \mathrm{P}_{\mathrm{A} \text {,s.s. }}$ and $\mathrm{P}_{\mathrm{D} \text {,s.s. }}$ were calculated using eqs. 1 and 4 , respectively. $P_{R, \text { s.s. }}$ was calculated as $1-P_{A_{\text {s.s.s. }}}-P_{D, \text { s.s. }}$. $\mathrm{P}_{\mathrm{A} \text { peak }}$ was calculated by assigning an arbitrary high value $\left(10^{7}\right)$ to $\mathrm{Q}$ (ratio of active to desensitized receptors) in eq. 1, effectively reducing the RAD model to a two-state Resting-Active model (Germann et al., 2019a). (B) shows the sum of the fractions of active and resting (i.e., activatable) receptors at different values of $\mathrm{P}_{\mathrm{A} \text {,s.s. }}$ (steady-state probability of being in the active state) with the value of $\mathrm{Q}$ constrained to 1000,1 , or 0.2 . The maximal values for $\mathrm{P}_{\mathrm{A} \text {,s.s. }}$ in the presence of saturating agonist are calculated as $1 /\left(1+1 /\left(\mathrm{Q} d^{\mathrm{N}}\right)+\mathrm{L} c^{\mathrm{N}}\right)$ and equal $0.83,0.46$, and 0.16 at these values of $Q$, whereas the corresponding values for the probability that a receptor is either resting or active are $0.99,0.54$, and 0.19 . 
At $\mathrm{Q}(=\mathrm{A} / \mathrm{D})$ of 1000 , the equilibrium between active and desensitized states is strongly biased toward active, and there is minimal desensitization. Accordingly, the sum of fractions of active + resting receptors $(\mathrm{A}+\mathrm{R})$ remains near 1 at all values of $\mathrm{P}_{\mathrm{A} \text {,s.s. }}$. When $\mathrm{Q}$ is constrained to 1 , in the presence of saturating agonist $\mathrm{X}, \sim 45 \%$ of receptors are in the active and desensitized states each, and $\sim 9 \%$ are in the resting state. When $\mathrm{Q}$ is 0.2 , the $\mathrm{P}_{\mathrm{A} \text {,s.s. }}$ in the presence of saturating [agonist] is $0.16,81 \%$ of receptors are in the desensitized state, and $\sim 3 \%$ are in the resting state. The reported experimentally determined values of $\mathrm{Q}$ for the $\mathrm{GABA}_{\mathrm{A}}$ receptor range from $\sim 0.2$ to 0.8 (Germann et al., 2019b; Pierce et al., 2019).

Activation and Desensitization Properties of the $\alpha 1 \beta 3 \gamma 2$ L GABA $\mathbf{A}$ Receptor. We tested the ability of the model to account for accumulation of $\alpha 1 \beta 3 \gamma 2 \mathrm{~L} \mathrm{GABA}_{\mathrm{A}}$ receptors in the desensitized state. We began by estimating the activation and desensitization properties of the $\alpha 1 \beta 3 \gamma 2 \mathrm{~L}$ receptor in the presence of GABA. Receptor activation by GABA was examined by measuring peak and steady-state current responses to $0.3 \mu \mathrm{M}$ to $1 \mathrm{mM}$ GABA. The $\mathrm{P}_{\mathrm{A}}$ of the responses was estimated by comparing the raw amplitudes of the peak and steady-state responses to the peak response to $1 \mathrm{mM}$ GABA $+50 \mu \mathrm{M}$ propofol recorded in the same cell. The latter was considered to have a $\mathrm{P}_{\mathrm{A}}$ indistinguishable from 1 (Ruesch et al., 2012; Shin et al., 2018).

Receptor activation parameters were determined as described in detail previously (e.g., Akk et al., 2018). The peak currents, in $\mathrm{P}_{\mathrm{A}}$ units, were fitted with the following equation (Forman, 2012; Steinbach and Akk, 2019):

$$
\mathrm{P}_{\mathrm{A}, \text { peak },[\mathrm{GABA}]}=\frac{1}{1+\mathrm{L}\left[\frac{1+[\mathrm{GABA}] / \mathrm{K}_{\mathrm{GABA}}}{1+[\mathrm{GABA}] /\left(\mathrm{K}_{\mathrm{GABA}} \mathrm{GABA}_{\mathrm{GA}}\right)}\right]^{\mathrm{N}_{\mathrm{GABA}}}}
$$

The number of binding sites for GABA $\left(\mathrm{N}_{\mathrm{GABA}}\right)$ was set to 2 , and L (= R/A) was constrained to 8000 (Shin et al., 2017; Akk et al., 2018). The analyses yielded a $\mathrm{K}_{\mathrm{GABA}}$ of $39.0 \pm 7.6$ (bestfit parameter \pm S.D. of the fit) and a $c_{\mathrm{GABA}}$ of $0.0027 \pm 0.0004$ ( $n=5$ to 6 cells per concentration). The steady-state currents from the same set of cells were analyzed using eq. 1, with $\mathrm{K}_{\mathrm{GABA}}$ and $c_{\mathrm{GABA}}$ constrained to the values determined in the analysis of peak responses and $d_{\mathrm{GABA}}$ held at 1 . The fitted value of $Q$ was $0.24 \pm 0.01$. Sample current traces are shown in Fig. 4A, and the concentration-response relationships for peak and steady-state currents are given in Fig. 4B.

Observed and Predicted Desensitization of the $\alpha 1 \beta 3 \gamma 2 L$ Receptor in the Presence of GABA or the Combination of GABA and the Steroid $3 \alpha 5 \alpha P$. Next, we employed the estimated activation and desensitization parameters to predict the degree of desensitization of the $\alpha 1 \beta 3 \gamma 2 \mathrm{~L}$ receptor after tonic exposure to agonist and to compare the RAD model-based predictions with the observed data. The RAD model predicts that the reduction in the response to a saturating concentration of agonist (that is, the amount of desensitization) is determined by the steady-state level of activation whether elicited by GABA alone or by GABA in the presence of a potentiation agent.

The experiments were conducted as shown in Fig. 1, and the probability of being desensitized at the end of the long pulse $\left(\mathrm{P}_{\mathrm{D}, \mathrm{s.s} .}\right)$ was calculated as $(1-$ ratio of the response to the second application to the response to the first). The data are expressed as steady-state probability of being desensitized at different levels of steady-state probability of being active at
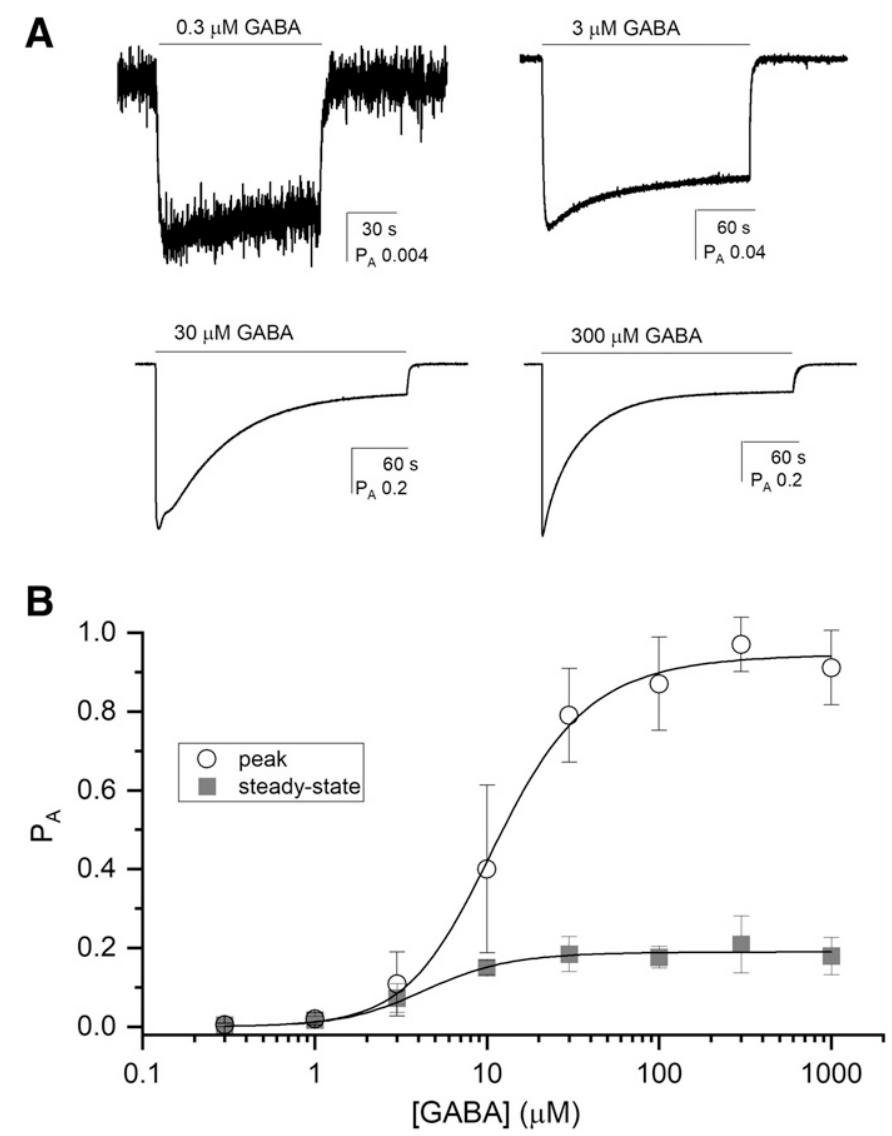

Fig. 4. Activation and desensitization of the $\alpha 1 \beta 3 \gamma 2 \mathrm{~L}$ GABA $\mathrm{A}$ receptor. (A) shows sample traces in the presence of $0.3,3,30$, or $300 \mu \mathrm{M}$ GABA. The amplitudes of peak and steady-state currents were converted to units of open probability $\left(\mathrm{P}_{\mathrm{A}}\right)$ by normalizing the current levels to the peak response to $1 \mathrm{mM}$ GABA $+50 \mu \mathrm{M}$ propofol in the same cell. (B) shows the peak and steady-state open probabilities as a function of GABA concentration. The data points show mean \pm S.D. from five to six cells per concentration. The curves were fitted with eq. 5 (peak data) or eq. 1 (steady-state data), yielding a $\mathrm{K}_{\mathrm{GABA}}$ of $39 \mu \mathrm{M}$, a $c_{\mathrm{GABA}}$ of 0.0027 , and a $\mathrm{Q}$ of 0.24 . The values of $\mathrm{L}$ and $\mathrm{N}_{\mathrm{GABA}}$ were held at 8000 and 2 , respectively.

the end of the long pulse (Fig. 5). We analyzed two data sets: one in which exposure to GABA was used to desensitize the receptor and the other in which the response to GABA was potentiated by the addition of $0.1-1 \mu \mathrm{M}$ of the neurosteroid $3 \alpha 5 \alpha \mathrm{P}$.

The data in Fig. 5 demonstrate that $\mathrm{P}_{\mathrm{D} \text {,s.s. }}$ increases with the $\mathrm{P}_{\mathrm{A}, \mathrm{s.s} .}$ of the desensitizing response. After exposure to $1 \mu \mathrm{M}$ GABA, which generated a steady-state response with $\mathrm{P}_{\mathrm{A}}$ of 0.014 , the $\mathrm{P}_{\mathrm{D}}$ was 0.064 , indicating a loss of $6.4 \%$ of theoretically available receptors. At a concentration producing a maximal $\mathrm{P}_{\mathrm{A} \text {,s.s. }}(\sim 0.2)$, the estimated $\mathrm{P}_{\mathrm{D}}$ was $\sim 0.8$. In other words, at saturating GABA, the vast majority $(\sim 98 \%)$ of receptors were either active or desensitized. There was no apparent difference for data recorded in the absence or presence of the steroid. Linear regression analysis provided estimates for the intercept and slope for data with GABA alone of $-0.02 \pm 0.05$ and $3.15 \pm 0.34$ and in the presence of $3 \alpha 5 \alpha \mathrm{P}$ of $-0.04 \pm 0.06$ and $3.36 \pm 0.42$. The slope of the linear regression was predicted to be $1 / \mathrm{Q}$ when $d=1$, so these values for the slope corresponded to values of $\mathrm{Q}$ of 0.32 and 0.30 .

The predicted $P_{D, s . s .}$ at various $P_{A, \text { s.s. }}$ was calculated using eq. 4 and is shown as a solid line in Fig. 5. The experimental observations qualitatively agree with the predictions of the 


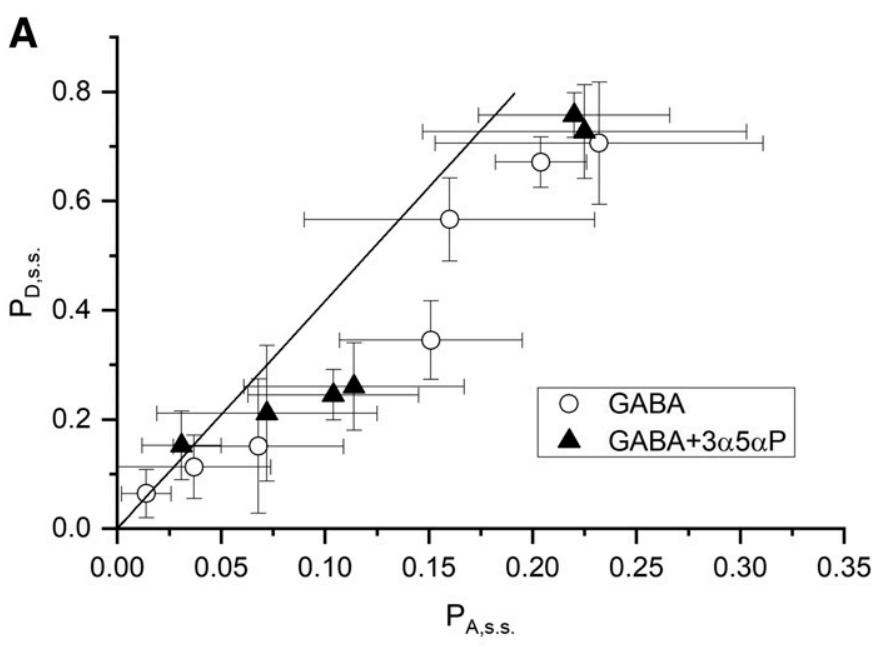

B

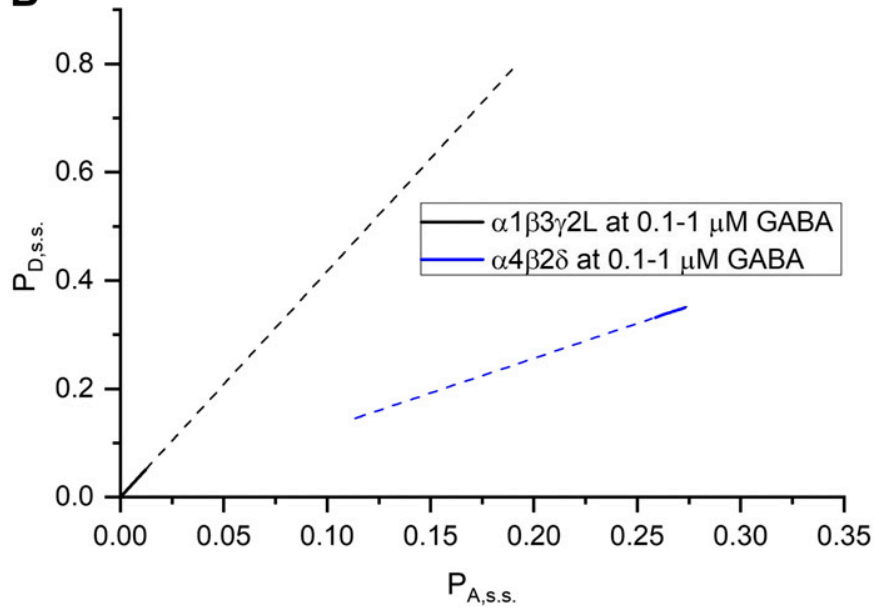

Fig. 5. Desensitization of the $\alpha 1 \beta 3 \gamma 2 \mathrm{~L} \mathrm{GABA}_{\mathrm{A}}$ receptor in the presence of GABA or GABA $+3 \alpha 5 \alpha$ P. Panel A shows the fraction of desensitized receptors $\left(\mathrm{P}_{\mathrm{D}, \mathrm{s.s} .}\right)$ after different levels of desensitizing activity $\left(\mathrm{P}_{\mathrm{A}, \mathrm{s.s}}\right)$ elicited by GABA or the combination of GABA $+3 \alpha 5 \alpha \mathrm{P}$. The data points give mean \pm S.D. from five to seven cells per experimental condition. For GABA, the symbols show data obtained in the presence of $1,2,5,10,30$, 100 , and $300 \mu \mathrm{M}$ GABA (order from low to high $\mathrm{P}_{\mathrm{A}, \mathrm{s.s}}$ ). For GABA $+3 \alpha 5 \alpha \mathrm{P}$, the symbols show data obtained in the presence of $1 \mu \mathrm{M}$ GABA $+0.1 \mu \mathrm{M}$ $3 \alpha 5 \alpha \mathrm{P}, 2 \mu \mathrm{M}$ GABA $+0.5 \mu \mathrm{M} 3 \alpha 5 \alpha \mathrm{P}, 3 \mu \mathrm{M}$ GABA $+1 \mu \mathrm{M} 3 \alpha 5 \alpha \mathrm{P}, 5 \mu \mathrm{M}$ $\mathrm{GABA}+1 \mu \mathrm{M} 3 \alpha 5 \alpha \mathrm{P}, 20 \mu \mathrm{M}$ GABA $+1 \mu \mathrm{M} 3 \alpha 5 \alpha \mathrm{P}$, and $100 \mu \mathrm{M} \mathrm{GABA}+1$ $\mu \mathrm{M} 3 \alpha 5 \alpha \mathrm{P}$ (order from low to high $\mathrm{P}_{\mathrm{A}, \mathrm{s.s}}$ ). The solid line is not fit to the data; it was calculated using eq. 4 and the activation and desensitization parameters established for the $\alpha 1 \beta 3 \gamma 2 \mathrm{~L}$ receptor $\left(\mathrm{K}_{\mathrm{GABA}}=39 \mu \mathrm{M}, c_{\mathrm{GABA}}=\right.$ $0.0027, \mathrm{~N}_{\mathrm{GABA}}=2, \mathrm{~L}=8000, \mathrm{Q}=0.24$ ) with no free parameters. In the absence of agonist, $\mathrm{P}_{\mathrm{Ass} \text {. }}$ is calculated as $1 /(1+1 / \mathrm{Q}+\mathrm{L})$. In the presence of saturating agonist, $\mathrm{P}_{\mathrm{A} \text {,s.s. }}$ is calculated as $1 /\left(1+1 /\left(\mathrm{Q} d^{\mathrm{N}}\right)+\mathrm{L} c^{\mathrm{N}}\right)$. (B) compares the fraction of desensitized receptors after different levels of desensitizing activity in the $\alpha 1 \beta 3 \gamma 2 \mathrm{~L}$ (black lines) and $\alpha 4 \beta 2 \delta$ receptor (blue lines). The activation and desensitization parameters for the $\alpha 4 \beta 2 \delta$ receptor are: $\mathrm{K}_{\mathrm{GABA}}=15.7 \mathrm{nM}, c_{\mathrm{GABA}}=0.45, \mathrm{~N}_{\mathrm{GABA}}=2, \mathrm{Q}=0.78$, and $\mathrm{L}=$ 6.7 (Pierce et al., 2019). The regions in the plot indicated with thick solid lines give the levels of $\mathrm{P}_{\mathrm{A}, \mathrm{s.s}}$ and the associated $\mathrm{P}_{\mathrm{D} \text {,s.s. }}$ in the presence of putative ambient GABA $(0.1-1 \mu \mathrm{M})$.

RAD model in two critical respects. First, there is a linear relationship between steady-state activation and desensitization $\left(R^{2}=0.94\right)$. Activation is a nonlinear function of [GABA], so this indicates that desensitization involves the same number of GABA-binding sites as activation; in the RAD model, the same sites are used for both physiologic responses. Furthermore, the linearity indicates that the affinities of the sites for activation and desensitization are the same (i.e., $d_{\mathrm{GABA}}$ is unity). Second, enhancement by $3 \alpha 5 \alpha \mathrm{P}$ of the steady-state response does not shift the relationship, indicating that activation rather than the concentration of agonist is the critical parameter connecting activation to desensitization.

\section{Discussion}

Synaptic events initiated by presynaptic release of GABA are interspersed with intervals when the concentration of the transmitter drops to low, background concentration. Although the level of tonic activity in synaptic receptors is low compared with the amplitude of a synaptic event, it has been suggested that the integrated charge transfer during the prolonged periods of tonic activity can exceed that during the shortlived IPSC occurring during the same period (Germann et al., 2019b). Furthermore, receptors exposed to ambient GABA undergo desensitization that reduces the number of receptors available for subsequent synaptic activation (Overstreet et al., 2000).

Here, we recorded the loss of receptor responsiveness after prolonged exposure to GABA or GABA $+3 \alpha 5 \alpha \mathrm{P}$. The major findings are summarized in Fig. 5, which illustrates the relationship between the level of steady-state activity $\left(\mathrm{P}_{\mathrm{A}, \mathrm{s.s} .}\right)$ and the fraction of desensitized receptors $\left(\mathrm{P}_{\mathrm{D} \text {,s.s. }}\right)$ [i.e., the relative number of receptors that are neither already active nor available for activation (resting)]. The level of steady-state activity indicates the fraction of receptors that are already active in the presence of the given agonist. The fraction of resting receptors can be calculated as $1-\mathrm{P}_{\mathrm{D} \text {,s.s. }}-\mathrm{P}_{\mathrm{A} \text {,s.s. }}$.

An increase in $\mathrm{P}_{\mathrm{A}, \mathrm{s.s}}$ is associated with an increase in $\mathrm{P}_{\mathrm{D}, \mathrm{s.s} \text {, }}$, the extent of which is determined by the parameter $\mathrm{Q}$. When $\mathrm{Q}$ is high (there is little desensitization), most receptors remain either active or activatable, whereas, in contrast, when $Q$ is low the majority becomes desensitized (Fig. 3B). We emphasize that for combinations of GABA and $3 \alpha 5 \alpha \mathrm{P}$, it is the overall level of activity that matters. Indeed, a decrease in [GABA] accompanied by an increase in $[3 \alpha 5 \alpha \mathrm{P}]$ that results in the same $\mathrm{P}_{\mathrm{A} \text {,s.s. }}$ results in the same observed $\mathrm{P}_{\mathrm{D} \text {,s.s. }}$ (Fig. 5).

In the absence of a GABAergic agonist, the $\alpha 1 \beta 3 \gamma 2$ receptors are minimally active $(\sim 1 / 8000)$ or desensitized $(\sim 4 / 8000)$, and the vast majority of receptors are available to respond to presynaptically released transmitter. The precise extent of desensitization of synaptic $\mathrm{GABA}_{\mathrm{A}}$ receptors is unclear because we do not know the true background concentration of GABA in the cleft. The concentration is likely strongly influenced by transmitter release frequency and the geometry of the synapse as well as expression of GABA transporters (Scimemi and Beato, 2009; Scimemi, 2014). Using 3D Monte Carlo reaction-diffusion simulations, Scimemi (2014) estimated a steady-state GABA concentration of $0.1-1 \mu \mathrm{M}$ in the cleft. This is similar to the concentration of measured in the cerebrospinal fluid (Lerma et al., 1986; de Groote and Linthorst, 2007; Zandy et al., 2017). Using the activation and desensitization parameters presented above, we estimate that in the presence of $0.1 \mu \mathrm{M}$ GABA, $0.05 \%$ of receptors are in the active state, and $0.2 \%$ are in the desensitized state. In the presence of $1 \mu \mathrm{M}$ GABA, $1.2 \%$ of the receptors are in the active state, and $5 \%$ are in the desensitized state. Thus, up to $5 \%$ of synaptic $\mathrm{GABA}_{\mathrm{A}}$ receptors are predicted to be unavailable for activation during a synaptic event simply as a consequence of being exposed to ambient GABA. In hippocampal neurons, exposure to 0.1 or $1 \mu \mathrm{M}$ GABA reduced the subsequent 
response to saturating GABA by $1.2 \%$ or $7.3 \%$, respectively (Orser et al., 1994). In the hippocampal autaptic preparation, pre-equilibration with $1 \mu \mathrm{M}$ of externally applied GABA reduced the amplitude of IPSCs by $23 \%$ (Overstreet et al., 2000).

Some portion of the synaptic response likely results from activation of $\delta$-subunit containing receptors (Wei et al., 2003; Herd et al., 2013; Sun et al., 2018). The GABA $_{A}$ receptor comprising $\alpha 4, \beta 2$, and $\delta$ subunits shows less desensitization to a given concentration of GABA with an estimated value of $\mathrm{Q}=0.8$ (Pierce et al., 2019). As indicated in Fig. 5B, this results in much less desensitization than what is observed for the $\alpha 1 \beta 3 \gamma 2$ receptor at comparable levels of steady-state levels of activation, suggesting that some synaptic transmission events would be more resistant to the desensitizing effects of increased tonic GABA or endogenous potentiator concentrations.

Other members of the pentameric ligand-gated ion channel family also show desensitization. In terms of rapidity and extent of the decay of the response to a high concentration of agonist, desensitization ranges from minimal for the homomeric $\rho \mathrm{GABA}_{\mathrm{A}}$ receptor (Amin and Weiss, 1994) to rapid and nearly complete for homomeric nicotinic $\alpha 7$ receptors (Peng et al., 1994; Corradi and Bouzat, 2016). The muscle nicotinic receptor has been most completely studied, and Auerbach (2012) has estimated the values of $\mathrm{L}$ and $c_{\mathrm{ACh}}$ (using our nomenclature) of about $1.3 \times 10^{6}$ and $2 \times 10^{-4}$, whereas Elenes and Auerbach (2002) reported an energy difference between the open and the most deeply desensitized state of about $4.5 \mathrm{kcal} / \mathrm{mol}$, corresponding to a $\mathrm{Q}$ value of $4 \times 10^{-4}$. These values correspond to values at saturating $\mathrm{ACh}$ of $\mathrm{P}_{\mathrm{A}, \mathrm{s.s}}$. of $4 \times 10^{-4}$ and $\mathrm{P}_{\mathrm{D} \text {,s.s. }}$ close to 1 . With estimated [ACh] in plasma $<5 \mathrm{nM}$, we can calculate that the fraction of desensitized muscle $\mathrm{ACh}$ receptors due to exposure to tonic $\mathrm{ACh}$ is $0.3 \%$.

The data presented here and previously (Orser et al., 1994; Overstreet et al., 2000) indicate that an increase in cleft GABA concentration increases tonic activity but may reduce phasic activity. Comparison of total charge transfer involving synaptic receptors demonstrates a net gain of $\sim 1 \mathrm{pC}$ (assuming 100 receptors with $1 \mathrm{pA}$ amplitude, a decay time constant of 30 milliseconds, and a frequency of $1 \mathrm{~Hz}$ and $\mathrm{P}_{\mathrm{A} \text {,peak }}$ of 1 for IPSCs) over 1 second when the cleft GABA concentration increases from 0.1 to $1 \mu \mathrm{M}$,i.e., the increase in tonic current from the synaptic receptor overcompensates for the decrease in phasic response. However, the net change in charge transfer after an increase in cleft [GABA] from 0.1 to $1 \mu \mathrm{M}$ becomes 0 when the frequency of IPCSs is $\sim 7 \mathrm{~Hz}$ and is negative (i.e., a net decrease in cellular inhibition) at frequencies above that. The reversal point for net change in total charge transfer $(\sim 7$ $\mathrm{Hz}$ ) is independent of the magnitude of change in [GABA] because both the increase in tonic and decrease in phasic current are governed by the same activation and desensitization parameters.

Exposure to allosteric agonists, such as the endogenous steroid allopregnanolone, similarly to GABA increases tonic activity and desensitizes receptors. However, the resulting inhibitory effect on peak phasic response is to a degree compensated by slower decay of IPSCs. The anesthetic propofol increases the amplitude of tonic activity but is less efficient at stabilizing desensitized receptors because it has higher affinity to the active than desensitized state $(d>1$;
Germann et al., 2019b). Accordingly, we predict minimal reduction in IPSC amplitude after exposure to propofol.

We emphasize that these calculations apply to a "closed system" involving solely synaptic $\mathrm{GABA}_{\mathrm{A}}$ receptors. An increase in ambient [GABA] is expected to enhance tonic activity from extrasynaptic receptors (Nusser et al., 1998; Bright et al., 2011) and activate presynaptic $\mathrm{GABA}_{\mathrm{B}}$ receptors to reduce presynaptic GABA release (Deisz and Prince, 1989; Khatri et al., 2019). It is not immediately clear what the overall sum effect is on the membrane potential of the postsynaptic cell.

This study adds to the growing body of evidence that synaptic $\mathrm{GABA}_{\mathrm{A}}$ receptors undergo activation and desensitization between synaptic events in the presence of the background level of the transmitter. Tonic activation can be a significant contributor to total charge transfer, whereas desensitization can reduce the peak amplitude of a synaptic response. The findings also suggest a somewhat paradoxical phenomenon in which an increase in ambient levels of GABAergic agents enhances tonic but reduces phasic activity from synaptic receptors with net change dependent on the frequency of phasic activity.

\section{Authorship Contributions}

Participated in research design: Evers, Steinbach, Akk.

Conducted experiments: Pierce, Germann.

Performed data analysis: Pierce, Germann, Akk.

Wrote or contributed to the writing of the manuscript: Pierce, Germann, Evers, Steinbach, Akk.

\section{References}

Akk G, Shin DJ, Germann AL, and Steinbach JH (2018) GABA type A receptor activation in the allosteric coagonist model framework: relationship between $\mathrm{EC}_{50}$ and basal activity. Mol Pharmacol 93:90-100

Amin J and Weiss DS (1994) Homomeric $\rho 1$ GABA channels: activation properties and domains. Receptors Channels 2:227-236.

Auerbach A (2012) Thinking in cycles: MWC is a good model for acetylcholine receptor-channels. $J$ Physiol 590:93-98.

Bianchi MT and Macdonald RL (2002) Slow phases of $\mathrm{GABA}_{\mathrm{A}}$ receptor desensitization: structural determinants and possible relevance for synaptic function J Physiol 544:3-18.

Bright DP, Renzi M, Bartram J, McGee TP, MacKenzie G, Hosie AM, Farrant M, and Brickley SG (2011) Profound desensitization by ambient GABA limits activation of $\delta$-containing $\mathrm{GABA}_{\mathrm{A}}$ receptors during spillover. $J$ Neurosci 31: $753-763$.

Clements JD (1996) Transmitter timecourse in the synaptic cleft: its role in central synaptic function. Trends Neurosci 19:163-171.

Corradi J and Bouzat C (2016) Understanding the bases of function and modulation of $\alpha 7$ nicotinic receptors: implications for drug discovery. Mol Pharmacol 90 288-299.

de Groote L and Linthorst AC (2007) Exposure to novelty and forced swimming evoke stressor-dependent changes in extracellular GABA in the rat hippocampus. Neuroscience 148:794-805.

Deisz RA and Prince DA (1989) Frequency-dependent depression of inhibition in guinea-pig neocortex in vitro by $\mathrm{GABA}_{\mathrm{B}}$ receptor feed-back on GABA release. J Physiol 412:513-541.

Draguhn A and Heinemann U (1996) Different mechanisms regulate IPSC kinetics in early postnatal and juvenile hippocampal granule cells. J Neurophysiol $\mathbf{7 6}$ : 3983-3993.

Edwards FA, Konnerth A, and Sakmann B (1990) Quantal analysis of inhibitory synaptic transmission in the dentate gyrus of rat hippocampal slices: a patchclamp study. J Physiol 430:213-249.

Elenes S and Auerbach A (2002) Desensitization of diliganded mouse muscle nicotinic acetylcholine receptor channels. $J$ Physiol 541:367-383.

Feng HJ, Bianchi MT, and Macdonald RL (2004) Pentobarbital differentially modulates $\alpha 1 \beta 3 \delta$ and $\alpha 1 \beta 3 \gamma 2 \mathrm{~L}_{\mathrm{GABA}}$ receptor currents. Mol Pharmacol 66: 988-1003.

Forman SA (2012) Monod-Wyman-Changeux allosteric mechanisms of action and the pharmacology of etomidate. Curr Opin Anaesthesiol 25:411-418.

Germann AL, Pierce SR, Burbridge AB, Steinbach JH, and Akk G (2019a) Steadystate activation and modulation of the concatemeric $\alpha 1 \beta 2 \gamma 2 \mathrm{~L} \mathrm{GABA}_{\mathrm{A}}$ Receptor. Mol Pharmacol 96:320-329.

Germann AL, Pierce SR, Senneff TC, Burbridge AB, Steinbach JH, and Akk G (2019b) Steady-state activation and modulation of the synaptic-type $\alpha 1 \beta 2 \gamma 2 \mathrm{~L}$ $\mathrm{GABA}_{\mathrm{A}}$ receptor by combinations of physiological and clinical ligands. Physiol Rep 7:e14230.

Herd MB, Brown AR, Lambert JJ, and Belelli D (2013) Extrasynaptic GABA receptors couple presynaptic activity to postsynaptic inhibition in the somatosensory thalamus. J Neurosci 33:14850-14868. 
Jones MV and Westbrook GL (1995) Desensitized states prolong GABA channel responses to brief agonist pulses. Neuron 15:181-191.

Khatri SN, Wu WC, Yang Y, and Pugh JR (2019) Mechanisms of GABA receptor $^{2}$ enhancement of extrasynaptic $\mathrm{GABA}_{\mathrm{A}}$ receptor currents in cerebellar granule cells. Sci Rep 9:16683.

Lerma J, Herranz AS, Herreras O, Abraira V, and Martín del Río R (1986) In vivo determination of extracellular concentration of amino acids in the rat hippocampus. A method based on brain dialysis and computerized analysis. Brain Res 384: 145-155

Michel MC, Murphy TJ, and Motulsky HJ (2020) New author guidelines for displaying data and reporting data analysis and statistical methods in experimental biology. Mol Pharmacol 97:49-60.

Monod J, Wyman J, and Changeux JP (1965) On the nature of allosteric transitions: a plausible model. J Mol Biol 12:88-118.

Mozrzymas JW, Barberis A, Michalak K, and Cherubini E (1999) Chlorpromazine inhibits miniature GABAergic currents by reducing the binding and by increasing the unbinding rate of $\mathrm{GABA}_{\mathrm{A}}$ receptors. J Neurosci 19:2474-2488.

Nusser Z, Hájos N, Somogyi P, and Mody I (1998) Increased number of synaptic $\mathrm{GABA}_{\mathrm{A}}$ receptors underlies potentiation at hippocampal inhibitory synapses. $\mathrm{Na}$ ture 395:172-177.

Orser BA, Wang LY, Pennefather PS, and MacDonald JF (1994) Propofol modulates activation and desensitization of $\mathrm{GABA}_{\mathrm{A}}$ receptors in cultured murine hippocampal neurons. $J$ Neurosci 14:7747-7760.

Overstreet LS, Jones MV, and Westbrook GL (2000) Slow desensitization regulates

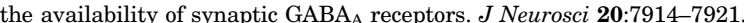

Overstreet LS, Westbrook GL, and Jones MV (2002) Measuring and modeling the spatiotemporal profile of GABA at the synapse, in Transmembrane Transporters (Quick MW ed) pp 259-276, Wiley-Liss, New York.

Peng X, Katz M, Gerzanich V, Anand R, and Lindstrom J (1994) Human $\alpha 7$ acetylcholine receptor: cloning of the $\alpha 7$ subunit from the SH-SY5Y cell line and determination of pharmacological properties of native receptors and functional $\alpha 7$ homomers expressed in Xenopus oocytes. Mol Pharmacol 45:546-554.

Pierce SR, Senneff TC, Germann AL, and Akk G (2019) Steady-state activation of the high-affinity isoform of the $\alpha 4 \beta 2 \delta$ GABA $_{\mathrm{A}}$ receptor. Sci Rep 9:15997.
Ruesch D, Neumann E, Wulf H, and Forman SA (2012) An allosteric coagonist model for propofol effects on $\alpha 1 \beta 2 \gamma 2 \mathrm{~L} \gamma$-aminobutyric acid type A receptors. Anesthesiology 116:47-55.

Scimemi A (2014) Plasticity of GABA transporters: an unconventional route to shape inhibitory synaptic transmission. Front Cell Neurosci 8:128.

Scimemi A and Beato M (2009) Determining the neurotransmitter concentration profile at active synapses. Mol Neurobiol 40:289-306.

Shin DJ, Germann AL, Johnson AD, Forman SA, Steinbach JH, and Akk G (2018) Propofol is an allosteric agonist with multiple binding sites on concatemeric ter-

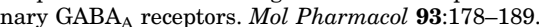

Shin DJ, Germann AL, Steinbach JH, and Akk G (2017) The actions of drug combinations on the GABA $\mathrm{A}_{\mathrm{A}}$ receptor manifest as curvilinear isoboles of additivity. $\mathrm{Mol}$ Pharmacol 92:556-563.

Steinbach JH and Akk G (2001) Modulation of GABA receptor channel gating by pentobarbital. J Physiol 537:715-733.

Steinbach JH and Akk G (2019) Applying the Monod-Wyman-Changeux allosteric activation model to pseudo-steady-state responses from $\mathrm{GABA}_{\mathrm{A}}$ receptors. $\mathrm{Mol}$ Pharmacol 95:106-119.

Sun MY, Shu HJ, Benz A, Bracamontes J, Akk G, Zorumski CF, Steinbach JH, and Mennerick SJ (2018) Chemogenetic isolation reveals synaptic contribution of $\delta$ $\mathrm{GABA}_{\mathrm{A}}$ receptors in mouse dentate granule neurons. $J$ Neurosci 38:8128-8145.

Wei W, Zhang N, Peng Z, Houser CR, and Mody I (2003) Perisynaptic localization of $\delta$ subunit-containing $\mathrm{GABA}_{\mathrm{A}}$ receptors and their activation by GABA spillover in the mouse dentate gyrus. $J$ Neurosci 23:10650-10661.

Zandy SL, Doherty JM, Wibisono ND, and Gonzales RA (2017) High sensitivity HPLC method for analysis of in vivo extracellular GABA using optimized fluorescence parameters for o-phthalaldehyde (OPA)/sulfite derivatives. J Chromatogr B Analyt Technol Biomed Life Sci 1055-1056:1-7.

Address correspondence to: Gustav Akk, Department of Anesthesiology, Washington University School of Medicine, Campus Box 8054, 660 S. Euclid Ave., St. Louis, MO 63110. E-mail: akk@morpheus.wustl.edu 